\title{
The Effect of Different Levels of Salinity and Potassium Nitrate on the Germination of Cocks Comb (Celosia cristata)
}

\author{
Zahra Golshadi Ghaleh-Shahi' ${ }^{1}$, Hossein Zarei ${ }^{1}$, Mehrdad Babarabie $^{2 *}$, Atoosa Danyaei ${ }^{3}$, \\ Madeh Ahmadi' ${ }^{1}$, Sima Badeli² \\ ${ }^{1}$ Department of Horticulture, Gorgan University of Agricultural Sciences and Natural Resources, Gorgan, Iran \\ ${ }^{2}$ Young Researchers and Elite Club, Gorgan Branch, Islamic Azad University, Gorgan, Iran \\ ${ }^{3}$ Department of Horticultural Sciences, Dr. Shariaty Faculty, Technical \& Vocational University, Tehran, Iran \\ Email: ${ }^{\star}$ m.babarabie@gau.ac.ir
}

How to cite this paper: Ghaleh-Shahi, Z.G., Zarei, H., Babarabie, M., Danyaei, A., Ahmadi, M. and Badeli, S. (2017) The Effect of Different Levels of Salinity and Potassium Nitrate on the Germination of Cocks Comb (Celosia cristata). Open Journal of Ecology, 7, 289-299.

https://doi.org/10.4236/oje.2017.74020

Received: February 17, 2017

Accepted: April 23, 2017

Published: April 26, 2017

Copyright $\odot 2017$ by authors and Scientific Research Publishing Inc. This work is licensed under the Creative Commons Attribution International License (CC BY 4.0).

http://creativecommons.org/licenses/by/4.0/

\begin{abstract}
Cocks Comb (Celosia cristata) is a hot-season annual species which is grown from seeds. A study was carried out in the horticulture laboratory of Gorgan University of Agriculture Science and Natural Resources of February 2013 to evaluate the impact of salinity and potassium nitrate on the germination of cockscomb with five salinity levels $(0,-2,-4,-6$, and -8 bars $)$ and three potassium nitrate levels $(0 \%, 0.2 \%$, and $0.4 \%)$ at $25^{\circ} \mathrm{C}$ on the basis of a Randomized Complete Block Design. Analysis of variance showed significant differences among salinity levels in germination percentage, radicle length, plumule length, and seed vigor at the $1 \%$ probability level. Mean comparison for germination percentage revealed that higher salinity reduced seed germination percentage so that it was decreased from $80 \%$ in no salinity to $15 \%$ in -8 $\mathrm{dS} \cdot \mathrm{m}^{-1}$. The highest percentage of germination was related to zero percent salt and potassium nitrate $0.2 \%$. Also, the highest radicle length of $2.48 \mathrm{~cm}$ was related to no salinity and the lowest one $(0.61 \mathrm{~cm})$ to $-6 \mathrm{dS}$ salinity. The highest radicle length and seed vigor were also observed in no salinity. Potassium nitrate by itself had no impact on the measured traits. Among interactions between salinity and potassium nitrate, the highest germination percentage was observed under 0 salinity $\times 0.2 \%$ potassium nitrate.
\end{abstract}

\section{Keywords}

Amarantaceae, Cocks Comb, Germination Percentage, Potassium Nitrate, Salinity

\section{Introduction}

Cocks Comb (Celosia cristata) is an annual growing up to $30-90 \mathrm{~cm}$ in height. 
Its inflorescence looks like a spike. The flowers are yellow, pink, red, and purple in color. They are very durable and can be dried and used as dry flower bunch for winter [1]. Cockscombs are propagated by the seeds [2]. It is highly heliotrope and despite it is drought resistant, keeping soil moisture in hot sunny days can help the production of good flowers [1]. Cockscombs are affected by soil salinity in arid and semi-arid regions due to high temperatures and evaporation and low precipitation. Salinity reduces water potential in root zone by reducing available water potential on the one hand and some ions leave toxic impacts on plants' physiological and biochemical processes on the other hand. Both phenomena disrupt the uptake of the nutrients by the roots, and finally, reduce plants' growth [3] [4]. Salinity susceptibility of plants (both agronomical and ornamental) varies at different growth stages [5].

Grime and Campbell (1991) stated that most plants show the highest susceptibility to salinity stress at germination and flowering stages, whereas suggesting seed germination stage as the most susceptible stage [6]. Seed germination percentage and rate are among the most effective factors in salinity stress conditions [5] [7].

One adverse impact of salinity on plants is the reduction of photosynthetic activity that results in the loss of chlorophyll, $\mathrm{CO}_{2}$ uptake, and photosynthetic capacity [8].

Germination percentage and rate are the most important factors among seed germination parameters that are affected by salinity stress [5].

Grime and Campbell (1991) stated that plants are the most susceptible to salinity stress at seed germination and early seedling growth [6]. Edward and Bison (1996) reported that the presence of certain ions and their effect on membrane permeability and germination-related enzymatic activity may accelerate germination under salinity stress [9].

There are various strategies to cope with the negative impacts of stresses. Seed priming is a method to reduce the adverse effects of stresses like salinity [10] [11], and to induce initial resistance to environmental stresses. As well, seed priming is a pre-germination physiological method to improve the seed yield and help quicker and more uniform germination [11]. The examination of the effect of different priming treatments on the germination of watermelon seeds under osmotic and thermal stresses revealed the loss of mean germination time and the increase in final germination of the seeds hydro-primed and primed with potassium nitrate as compared to control [12]. In another study, priming with potassium nitrate improved the germination of the sunflower seeds in salinity stress and hydropriming had the most favorable influence on radicle and plumule growth [13]. As salinity stress was intensified, the sunflower seeds primed with potassium nitrate and sodium chloride exhibited higher emergence rate than the unprimed seeds [14].

Today, the saline lands are growing by improper management and other related activities. As previous studies have shown, seed priming can be a good managerial approach to improve plant growth under environmental stresses, especially soil and irrigation water salinity. 
Potassium nitrate is a widely used chemical for germination enhancement. The $0.1 \%$ and $0.2 \%$ solutions are common in conventional germination trials and have been recommended by AOSA and ISTA for the germination trial on most species [15].

The present study aimed at examining the influence of different treatments of salinity and potassium nitrate on germination parameters of Cocks Comb (Celosia cristata) seeds and determining their salinity resistance.

\section{Materials and Methods}

The experiment was carried out in horticulture laboratory of Gorgan University of Agriculture Science and Natural Resources, as a factorial experiment based on Randomized Complete Block Design. The experimental treatments included five levels of salinity stress $(2,0,-4,-6$ and -8 bars) and three levels of potassium nitrate $\left(0 \%, 0.2 \%\right.$ and $\left.0.4 \% \mathrm{KNO}_{3}\right)$ with three replications and 30 seeds in each replication [16]. The prepared $F_{1}$ seeds were cultured in sterilized Petri dishes and then, they were applied with the different levels of salinity stress. To apply potassium nitrate treatments, the seeds were soaked in pre-prepared potassium nitrate solution for two hours. Then, they were placed in the Petri dishes and distilled water was added to them. Afterwards, the seed-containing Petri dishes were placed in an incubator at $25^{\circ} \mathrm{C}$, and the germinated seeds were counted twice a day (in the morning and evening) to estimate germination percentage. The trait measurements were terminated after germination and cotyledon growth stopped. The measured traits included germination percentage, germination speed, seed vigor, plumule length, radicle length, plumule fresh weight, radicle fresh weight, and normal seedling.

Germination speed (GR) was estimated by the following equation [16].

Formula 1:

$$
\begin{aligned}
\text { GR }= & \frac{\text { Germinated seed number at the first day }}{\text { Days to the first counting }}+\cdots \\
& +\frac{\text { Germinated seed number at the last day }}{\text { Days to the last counting }}
\end{aligned}
$$

The following equation was used to estimate seed vigor [17].

Formula 2:

Seed vigor index

$=\frac{\text { Mean plumule length }(\text { in } \mathrm{mm}) \times \text { germination percentage }}{100}$

Germination percentage was obtained from the following equation [18].

Formula 3:

$$
\text { Germination percentage }=\frac{\text { Number of germinated seeds }}{\text { Total number of seeds }}
$$

Plumule and radicle lengths were measured by a ruler, and their fresh weights were read on a digital scale. Normal seedlings were also counted in each replication when they were green and the cotyledons were fully grown. 
The collected data were statistically analyzed by SAS Software Package, and the means were compared by the LSD test at the $1 \%$ and $5 \%$ probability levels. Graphs were, also, drawn by MS-Excel Software Package.

\section{Results}

Analysis of variance showed that germination percentage and speed, seed vigor, plumule and radicle length, plumule and radicle fresh weight, and normal seedlings were significantly affected by different levels of salinity and their interactions with potassium nitrate at the $1 \%$ and $5 \%$ probability level (Table 1 ).

\subsection{Germination Percentage}

According to means comparison, the highest germination percentage $(80.05 \%)$ was obtained from no salinity, and potassium nitrate did not change it significantly. Among interactions, the highest germination percentage of $88.33 \%$ was obtained from no salinity and no nitrate potassium application, which did not have significant differences with the application of $0.2 \% \mathrm{KNO}_{3}$ under -2 bars salinity and $0.2 \% \mathrm{KNO}_{3}$ under -4 bars salinity (Tables $2-4$ ).

\subsection{Germination Speed}

Means comparison revealed that the maximum germination rate (5.57) was obtained from no salinity level, and $\mathrm{KNO}_{3}$ could not by itself affect it significantly. Among interactions, the highest germination rate (5.94) was observed in $0.4 \%$

Table 1. Analysis of variance of measured characteristics of Cocks Comb under salinity stress.

\begin{tabular}{|c|c|c|c|c|c|c|c|c|c|}
\hline S.O.V & $\mathrm{df}$ & $\begin{array}{l}\text { Germination } \\
\text { percentage }\end{array}$ & $\begin{array}{c}\text { Germination } \\
\text { speed }\end{array}$ & $\begin{array}{l}\text { Plumule } \\
\text { length }\end{array}$ & $\begin{array}{l}\text { Radicle } \\
\text { length }\end{array}$ & $\begin{array}{l}\text { Plumule fresh } \\
\text { weight }\end{array}$ & $\begin{array}{l}\text { Radicle fresh } \\
\text { weight }\end{array}$ & Seed vigor & $\begin{array}{c}\text { Normal seedling } \\
\text { percentage }\end{array}$ \\
\hline Nitrate & 2 & $170.556^{\mathrm{ns}}$ & $0.056^{\mathrm{ns}}$ & $0.001^{\mathrm{ns}}$ & $0.023^{\mathrm{ns}}$ & $1503.438^{* *}$ & $0.0000072^{\mathrm{ns}}$ & $196.519^{* *}$ & $166.280^{\mathrm{ns}}$ \\
\hline Salinity & 4 & $6524.444^{* *}$ & $34.308^{* *}$ & $7.831^{* *}$ & $8.777^{* *}$ & $315.598^{* *}$ & $0.00028^{* *}$ & $1205.900^{* *}$ & $10464.821^{* *}$ \\
\hline $\begin{array}{l}\text { Salinity } \times \\
\text { Nitrate }\end{array}$ & 8 & $124.028^{\mathrm{ns}}$ & $0.574^{\mathrm{ns}}$ & $0.078^{\text {ns }}$ & $0.454^{\star}$ & $311.870^{* *}$ & $0.0000013^{\mathrm{ns}}$ & $319.183^{\star *}$ & $85.628^{\mathrm{ns}}$ \\
\hline Error & 30 & 125.000 & 0.878 & 0.052 & 0.160 & 8.244 & 0.00001344 & 27.781 & 113.938 \\
\hline
\end{tabular}

${ }^{*},{ }^{*}$ and ${ }^{\mathrm{ns}}$ : Respectively significant difference and at $5 \%$ and $1 \%$ and non-significant.

Table 2. The effect of salinity stress on measured characteristics of Cocks Comb.

\begin{tabular}{|c|c|c|c|c|c|c|c|c|}
\hline Salinity & $\begin{array}{c}\text { Germination } \\
\text { percentage (\%) }\end{array}$ & $\begin{array}{l}\text { Germination } \\
\text { speed (Number } \\
\text { of germinated } \\
\text { seeds in day) }\end{array}$ & $\begin{array}{c}\text { Plumule } \\
\text { length }(\mathrm{cm})\end{array}$ & $\begin{array}{c}\text { Radicle } \\
\text { length }(\mathrm{cm})\end{array}$ & $\begin{array}{l}\text { Plumule fresh } \\
\text { weight (g) }\end{array}$ & $\begin{array}{l}\text { Radicle fresh } \\
\text { weight (g) }\end{array}$ & $\begin{array}{c}\text { Seed vigor } \\
(\%)\end{array}$ & $\begin{array}{c}\text { Normal } \\
\text { seedling } \\
\text { percentage }\end{array}$ \\
\hline 0 & $80.56^{\mathrm{a}}$ & $5.57^{\mathrm{a}}$ & $2.26^{\mathrm{a}}$ & $2.48^{\mathrm{a}}$ & $13.09^{\mathrm{a}}$ & $0.015^{\mathrm{a}}$ & $31.21^{\mathrm{a}}$ & $85.19^{\mathrm{a}}$ \\
\hline-2 bars & $76.11^{\mathrm{ab}}$ & $5.041^{\mathrm{ab}}$ & $2.22^{\mathrm{a}}$ & $1.87^{\mathrm{b}}$ & $10.27^{\mathrm{b}}$ & $0.008^{b}$ & $25.28^{\mathrm{b}}$ & $80.48^{a}$ \\
\hline-4 bars & $71.67^{\mathrm{ab}}$ & $4.45^{\mathrm{bc}}$ & $1.85^{\mathrm{b}}$ & $1.35^{\mathrm{c}}$ & $5.76^{c}$ & $0.008^{b}$ & $23.1^{\mathrm{b}}$ & $62.8^{\mathrm{b}}$ \\
\hline-6 bars & $69.44^{\mathrm{b}}$ & $4.062^{c}$ & $1.41^{\mathrm{c}}$ & $0.61^{d}$ & $0.026^{\mathrm{d}}$ & $0.006^{\mathrm{b}}$ & $14.08^{c}$ & $51.87^{\mathrm{c}}$ \\
\hline-8 bars & $15^{c}$ & $0.61^{\mathrm{d}}$ & $0^{\mathrm{d}}$ & $0^{\mathrm{d}}$ & $0^{\mathrm{d}}$ & $0^{c}$ & $1.5^{\mathrm{d}}$ & $0^{\mathrm{d}}$ \\
\hline
\end{tabular}

In each column, means with the similar letters are not significantly different at $5 \%$ level of probability using LSD test. 
Table 3. The effect of potassium nitrate on measured characteristics of Cocks Comb.

\begin{tabular}{ccccccccc}
\hline $\begin{array}{c}\text { Potassium } \\
\text { nitrate levels }\end{array}$ & $\begin{array}{c}\text { Germination } \\
\text { percentage }\end{array}$ & $\begin{array}{c}\text { Germination speed } \\
\text { (Number of } \\
\text { germinated } \\
\text { seeds in day) }\end{array}$ & $\begin{array}{c}\text { Plumule } \\
\text { length }(\mathrm{cm})\end{array}$ & $\begin{array}{c}\text { Radicle } \\
\text { length }(\mathrm{cm})\end{array}$ & $\begin{array}{c}\text { Plumule } \\
\text { fresh } \\
\text { weight }(\mathrm{g})\end{array}$ & $\begin{array}{c}\text { Radicle fresh } \\
\text { weight(g) }\end{array}$ & $\begin{array}{c}\text { Seed } \\
\text { vigor (\%) }\end{array}$ & $\begin{array}{c}\text { Normal } \\
\text { seedling } \\
\text { percentage }\end{array}$ \\
\hline zero & $58.66^{\mathrm{a}}$ & $3.93^{\mathrm{a}}$ & $1.54^{\mathrm{a}}$ & $1.24^{\mathrm{a}}$ & $17.39^{\mathrm{a}}$ & $0.008^{\mathrm{a}}$ & $20.25^{\mathrm{a}}$ & $2.24^{\mathrm{a}}$ \\
$0.2 \%$ & $64.66^{\mathrm{a}}$ & $4.01^{\mathrm{a}}$ & $1.56^{\mathrm{a}}$ & $1.24^{\mathrm{a}}$ & $0.30^{\mathrm{b}}$ & $0.007^{\mathrm{a}}$ & $19.94^{\mathrm{a}}$ & $57.66^{\mathrm{a}}$ \\
$0.4 \%$ & $64.33^{\mathrm{a}}$ & $3.89^{\mathrm{a}}$ & $1.54^{\mathrm{a}}$ & $1.31^{\mathrm{a}}$ & $0.07^{\mathrm{b}}$ & $0.007^{\mathrm{a}}$ & $21.89^{\mathrm{a}}$ & $58.30^{\mathrm{a}}$ \\
\hline
\end{tabular}

In each column, means with the similar letters are not significantly different at $5 \%$ level of probability using LSD test.

Table 4. The interaction between salinity stress and potassium nitrate on measured characteristics of Cocks Comb.

\begin{tabular}{|c|c|c|c|c|c|c|c|c|c|}
\hline $\begin{array}{l}\text { Potassium } \\
\text { Nitrate }\end{array}$ & salinity & $\begin{array}{c}\text { Germination } \\
\text { percentage } \\
(\%)\end{array}$ & $\begin{array}{c}\text { Germination } \\
\text { speed } \\
\text { (Number of } \\
\text { germinated } \\
\text { seeds in day) }\end{array}$ & $\begin{array}{l}\text { Plumule } \\
\text { length } \\
(\mathrm{cm})\end{array}$ & $\begin{array}{c}\text { Radicle } \\
\text { length } \\
(\mathrm{cm})\end{array}$ & $\begin{array}{l}\text { Plumule } \\
\text { fresh } \\
\text { weight } \\
\text { (g) }\end{array}$ & $\begin{array}{l}\text { Radicle } \\
\text { fresh } \\
\text { weight } \\
\text { (g) }\end{array}$ & $\begin{array}{l}\text { Seed } \\
\text { vigor } \\
(\%)\end{array}$ & $\begin{array}{c}\text { Normal } \\
\text { seedling } \\
\text { percentage } \\
(\%)\end{array}$ \\
\hline \multirow{4}{*}{ zero } & zero & $88.33^{\mathrm{a}}$ & $5.33^{\mathrm{a}}$ & $2.26^{\mathrm{a}}$ & $2.50^{\mathrm{a}}$ & $39.21^{\mathrm{a}}$ & $0.01^{\mathrm{a}}$ & $39.21^{\mathrm{a}}$ & $84.74^{\mathrm{a}}$ \\
\hline & -4 & $63.33^{\mathrm{cd}}$ & $4.94^{\mathrm{ab}}$ & $1.7^{\mathrm{b}}$ & $1^{\mathrm{bc}}$ & $17.23^{c}$ & $0.009^{\mathrm{dc}}$ & $17.23^{\mathrm{d}}$ & $55.19^{d}$ \\
\hline & -6 & $58.33^{\mathrm{d}}$ & $3.53^{c}$ & $1.53^{\mathrm{b}}$ & $0.62^{\mathrm{cd}}$ & $0.02^{\mathrm{d}}$ & $0.007^{b c}$ & $12.47^{\mathrm{d}}$ & $39.62^{\mathrm{e}}$ \\
\hline & -8 & $18.33^{\mathrm{e}}$ & $0.85^{\mathrm{d}}$ & $0^{c}$ & $0^{\mathrm{d}}$ & $0^{\mathrm{d}}$ & $0^{\mathrm{d}}$ & $1.83^{\mathrm{e}}$ & $0^{\mathrm{f}}$ \\
\hline \multirow{4}{*}{$\begin{array}{c}0.2 \\
\text { percentage }\end{array}$} & zero & $81.66^{\mathrm{ab}}$ & $5.44^{\mathrm{a}}$ & $2.43^{\mathrm{a}}$ & $2.46^{\mathrm{a}}$ & $0.03^{\mathrm{d}}$ & $0.01^{\mathrm{a}}$ & $1.83^{\mathrm{e}}$ & $85.66^{a}$ \\
\hline & -4 & $76.66^{\mathrm{bc}}$ & $4.62^{\mathrm{b}}$ & $1.73^{\mathrm{b}}$ & $0.96^{b c}$ & $0.03^{\mathrm{d}}$ & $0.007^{\mathrm{bc}}$ & $21.01^{\mathrm{cd}}$ & $64.55^{\mathrm{c}}$ \\
\hline & -6 & $76.66^{\mathrm{bc}}$ & $4.44^{\mathrm{b}}$ & $1.33^{\mathrm{b}}$ & $0.63^{\mathrm{cd}}$ & $0.03^{\mathrm{d}}$ & $0.006^{\mathrm{b}}$ & $15.13 d$ & $60.11^{\mathrm{cd}}$ \\
\hline & -8 & $8.33^{\mathrm{f}}$ & $0.32^{\mathrm{d}}$ & $0^{c}$ & $0^{\mathrm{d}}$ & $0^{\mathrm{d}}$ & $0^{\mathrm{d}}$ & $0.83^{\mathrm{e}}$ & $0^{\mathrm{f}}$ \\
\hline \multirow{5}{*}{$\begin{array}{c}0.4 \\
\text { percentage }\end{array}$} & zero & $76.66^{\mathrm{bc}}$ & $5.94^{\mathrm{a}}$ & $2.10^{\mathrm{a}}$ & $2.50^{\mathrm{a}}$ & $0.03^{\mathrm{d}}$ & $0.01^{\mathrm{a}}$ & $34.81^{\mathrm{ab}}$ & $85.17^{\mathrm{a}}$ \\
\hline & -2 & $78.33^{c}$ & $4.86^{\mathrm{b}}$ & $2.13^{\mathrm{a}}$ & $1.36^{\mathrm{b}}$ & $0.28^{\mathrm{d}}$ & $0.008^{c}$ & $27.11^{b c}$ & $81.78 \mathrm{ab}$ \\
\hline & -4 & $75^{\mathrm{bc}}$ & $3.79^{c}$ & $2.13^{\mathrm{a}}$ & $2.10^{\mathrm{a}}$ & $0.03^{\mathrm{d}}$ & $0.008^{c}$ & $31.06^{\mathrm{e}}$ & $68.67^{\mathrm{c}}$ \\
\hline & -6 & $73^{\mathrm{bc}}$ & $4.21^{\mathrm{b}}$ & $1.36^{\mathrm{b}}$ & $0.6^{\mathrm{cd}}$ & $0.02^{\mathrm{d}}$ & $0.005^{\mathrm{b}}$ & $14.63^{\mathrm{d}}$ & $55.87^{\mathrm{d}}$ \\
\hline & -8 & $88.33^{\mathrm{a}}$ & $5.33^{\mathrm{a}}$ & $2.26^{\mathrm{a}}$ & $2.50^{\mathrm{a}}$ & $39.21^{\mathrm{a}}$ & $0.01^{\mathrm{a}}$ & $39.21^{\mathrm{a}}$ & $84.74^{\mathrm{a}}$ \\
\hline
\end{tabular}

In each column, means with the similar letters are not significantly different at $5 \%$ level of probability using LSD test.

$\mathrm{KNO}_{3}$ and no salinity, but it showed no significant differences with the interaction of $0 \% \mathrm{KNO}_{3} \times 0$ salinity, $0 \% \mathrm{KNO}_{3} \times-2$ bars salinity, $0.2 \% \mathrm{KNO}_{3} \times 0$ salinity, and $0.2 \% \mathrm{KNO}_{3} \times-2$ bars salinity. The lowest germination rate (0.61) was observed at salinity level of -8 bars (Tables $2-4$ ).

\subsection{Plumule Length}

According to means comparison, the maximum plumule length was observed at no salinity level and among interactions, the maximum one was observed in $0.2 \% \mathrm{KNO}_{3} \times 0$ bars salinity. The minimum plumule length was related to -6 bars salinity, and no plumule grew at -8 bars salinity. $\mathrm{KNO}_{3}$ could not alone make any significant differences in plumule length (Tables 2-4). 


\subsection{Radicle Length}

Means comparison showed that the maximum radicle length was related to 0 bars salinity and that among interactions, $0 \% \mathrm{KNO}_{3} \times 0$ bars salinity and $0.4 \%$ $\mathrm{KNO}_{3} \times 0$ bars salinity were related to the maximum radicle length. The lowest radicle length was observed at salinity level of -6 bars and no radicles were produced at salinity level of -8 bars. Potassium nitrate could not alone change radicle length significantly (Tables $2-4$ ).

\subsection{Plumule Fresh Weight}

Means comparison showed the maximum plumule fresh weight at salinity level of 0 bars and among interactions, under $0 \% \mathrm{KNO}_{3} \times 0$ bars salinity. The lowest plumule fresh weight was observed at salinity level of -6 bars and no radicles were produced at salinity level of -8 bars. Among different rates of potassium nitrate, the highest plumule fresh weight was observed at $0 \% \mathrm{KNO}_{3}$ rate (Tables 2-4).

\subsection{Radicle Fresh Weight}

As means comparison showed, the maximum radicle fresh weight was observed at salinity level of 0 bars and among interactions, under $0 \% \mathrm{KNO}_{3} \times 0$ bars salinity, $0.2 \% \mathrm{KNO}_{3} \times 0$ bars salinity, and $0.4 \% \mathrm{KNO}_{3} \times 0$ bars salinity. Salinity levels of $-2,-4$ and -6 bars exhibited no significant differences in radicle fresh weight, and no radicles were observed at -8 bars salinity. Potassium nitrate by itself could not affect radicle fresh weight significantly (Tables $2-4$ ).

\subsection{Seed Vigor}

According to means comparison, the maximum seed vigor was associated with 0 bars salinity and no significant differences were found among different rates of potassium nitrate in seed vigor. Among interactions, the highest seed vigor was observed at $0 \% \mathrm{KNO}_{3} \times 0$ bars salinity which was not significantly different from that obtained from $0.2 \% \mathrm{KNO}_{3} \times 0$ bars salinity and $0.4 \% \mathrm{KNO}_{3} \times 0$ bars salinity (Tables 2-4).

\subsection{Normal Seedling Percentage}

As means comparison revealed, maximum normal seedling percentage was obtained from 0 and -2 bars salinity. Potassium nitrate did not influence normal seedling percentage significantly. Among interactions, the highest normal seedling percentage was obtained from the application of $0 \%, 0.2 \%$ or $0.4 \% \mathrm{KNO}_{3}$ under no salinity. It was not significantly different from that obtained from the interaction of $0 \%, 0.2 \%$, or $0.4 \% \mathrm{KNO}_{3}$ with -2 bars salinity (Tables $2-4$ ).

\section{Discussion}

As the salinity is intensified and the electrical conductivity of the solution is increased from control to $12 \mathrm{dS}$, germination percentage is lost [16].

According to Fenando et al. (2000), the increase in salinity resulted in the loss 
of germination of Chenopodium quinona [3]. In addition, Rajabi and Poustini (2005) reported that 0 and $3 \mathrm{dS} \cdot \mathrm{m}^{-1}$ salinities were significant different in terms of germination percentage and that the stress caused ion toxicity and the loss of germination [7].

The loss of germination percentage and rate by higher salinity can be related to the excessive presence of cations and anions that, beside causing toxicity, reduce water potential because of their solubility in water, so that despite the existence of water in the environment, their reactionary capacity is occupied by the ions and so, plants cannot uptake them, facing a kind of water deficiency [19].

In Rajabi and Poustini (2005) and Khaleghi and Moallemi (2009), higher salinity and EC decreased root length [7] [16].

Overall, the loss of germination and seedling growth under higher concentrations of salts in the medium is related the physico-chemical effects or toxic-osmotic consequences of the minerals contained in saline solution. In fact, as osmotic pressure is increased by higher salinity of the medium, seed imbibitions are disrupted on the one hand, and higher concentration of anions and cations in the medium becomes toxic to seeds, hindering their germination [4] [7]. Furthermore, the negative impacts of salinity on membrane permeability, cell division, protein synthesis, and enzymatic activity extends mean germination time and reduces germination speed and radicle elongation [20].

In a study on Aragania spinosa, significant differences were found among salinity levels in germination rate, radicle length, and dry weight and as salinity concentration was increased, germination time was not affected; rather, germination rate, root length, and radicle dry weight were decreased [21]. Also, relatively numerous studies on different plants have shown that higher salinity results in the loss of plumule and radicle length and dry weight as compared to control [22].

The increase in salinity level under in vitro conditions was associated with the loss of germination percentage of all priming treatments, so that $4 \mathrm{dS} \cdot \mathrm{m}^{-1}$ salinity resulted in lower germination percentage in control, hydroprimed seeds and seeds primed with 3 and $6 \mathrm{~g} \cdot \mathrm{l}^{-1} \mathrm{KNO}_{3}$ than no salinity by $34 \%, 14 \%$ and $10 \%$ [23].

Higher germination percentage and emergence of primed seeds under salinity conditions are related to the fulfillment of some germination processes during seed priming including imbibitions and the synthesis of nucleic acids [24] which shortens germination time and then, seeds would need shorter time for germination that unprimed seeds under salinity conditions. Furthermore, mean germination time and emergence are important factors in improving emergence percentage of primed seeds under stress conditions as compared to control (unprimed) seeds. It has been suggested that faster exit of radicle and plumule from primed seeds is caused by more efficient water uptake and metabolic activity during germination [25] and that higher water uptake capability of primed seeds vs. unprimed seeds influences germination percentage and rate positively [26]. Also, accelerated germination of primed seeds can be related to higher cell divi- 
sion rate in these seeds [27] and the stimulation of some metabolic activities engaged in the first phase of germination [28].

It has been reported that the priming of cotton seeds decreased mean germination and emergence time, thereby playing a key role in improving the measured parameters of the seedlings in laboratorial conditions and of the greenhouse-grown plants [23]. Indeed, priming shortened this phase of plant life, helping them to exploit the environmental resources for the growth and salinity adaptation more quickly. Also in unstressed conditions, seed hydropriming can be a good strategy to improve initial growth of the cotton plants due to its inexpensiveness and availability in different conditions. However, in case of the salinity stress, priming with the appropriate dosages of potassium nitrate (below toxicity level) can be a suitable method to make the cotton plants cv. "Sahel" and the resulting seedlings stress resistant.

The salinity induced loss of plant growth may be caused by the disruption of the uptake of the nutrients, disturbance of ion balance or the loss of water potential in soil and osmotic stress, or may be caused by the variation of the availability of the enzymes effective on photosynthesizing system. Stem and root length are the main parameters to monitor the impact of environmental stresses, especially salinity and drought because root is in a direct contact with soil absorbing water and minerals and stem mobilizes them towards other parts. Therefore, the longitudinal variations of these two parameters (stem and root) signal the plant responses to drought stress [29].

The desirable impact of seed priming on germination percentage and rate has been reported by many studies. For example, Demir Kaya et al. (2006) observed higher germination percentage and rate in sunflower seeds primed with potassium nitrate under salinity stress [12]. Farooqh et al. (2006) related germination improvement of two rice cultivars to priming with potassium chloride and calcium chloride [30]. Germination rate has been reported to be improved by hydropriming in plants like corn and cotton [31]. Some researchers suggest that higher water uptake in the primed seeds vs. unprimed seeds positively affected germination percentage and rate [26].

Some studies have revealed the improvement of radicle and plumule length in primed seeds. It has been shown that seed priming with potassium nitrate increased radicle and plumule length of seedlings grown from the seeds of different plants under salinity conditions [32].

Kattimani et al. (1999) reported higher seed vigor due to priming with nitrate solutions [33] and Artola et al. (2003) noted the favorable impact of hydropriming on the seed vigor of Melilotus officinalis [34].

Soleimani et al. (2012) concluded that salinity reduced germination percentage and rate, plumule and radicle length, seedling fresh weight, and seed vigor [23]. The species did not show similar responses to different pre-treatments, so that priming of Nigella sativa with potassium nitrate, distilled water, and potassium chloride improved germination and seedling features under salinity but priming with calcium chloride and sodium chloride did not have any positive 
effects.

\section{Conclusion}

Germination percentage was $80.05 \%$ in control, reached $69.44 \%$ at -6 bars salinity and was reduced to as low as $15 \%$ under -8 bars salinity. So, it can be said that Cocks Comb (Celosia cristata) is a semi-resistant species to salinity. Also, normal seedling percentage was $85.19 \%$ in control which was reduced to $51.87 \%$ in -6 bars salinity. Most traits were lost by higher salinity. Potassium nitrate by itself had no significant effect on the measured traits, but its interaction with salinity was significant for radicle length, plumule weight, and seed vigor.

\section{References}

[1] Dole, J.M. and Wilkins, H.F. (1999) Floriculture: Principle and Species. Viacom Press, New Jersey, 613 p.

[2] Khalighi, A. (1991) Floriculture and Ornamental Plants of Iran. Rozbahan Press, Tehran, $392 \mathrm{p}$.

[3] Fenando, E.P., Boero, C., Gallardo, M. and Gonzalez, J. (2000) Effect of $\mathrm{NaCl}$ on Germination, Growth, and Soluble Sugar Content in Chenopodium quinona Seeds. Botanical Bulletin of Academia Sinica, 41, 27-34.

[4] Khaleghi, E. and Ramin, A.A. (2005) Study of the Effects of Salinity on Growth and Development of Lawns (Lolium perenne L., Festuca arundinacean and Cynodon dactylon). Journal of Agricultural Science and Technology, 9, 57-68.

[5] Mirmohammadi Meybodi, A.M. and Ghareriazi, B. (2002) Physiological Aspects and Breeding For Salinity Stress in Plants. Publication of Isfahan University of Technology, Isfahan, Iran 288 p.

[6] Grime, J.P. and Campbell, B.D. (1991) Growth Rate, Habitat Productivity, and Plant Strategy as Predicators of Stress Response. Academic Press, London, 422 p.

[7] Rajabi, R. and Poustini, K. (2005) Effect of $\mathrm{NaCl}$ on Thirty Caltivars of Bread Wheat Seed Germination. Agriculture Science Journal, 27, 29-45.

[8] Irma, T., Jolan, C., Gabriella, S., Ferenc, H., Attila, P., Gabriella, K., Agnes, S., Margit, S. and Lazlo, E. (2002) Acclimation of Tomato Plants to Salinity Stress after a Salicylic Acid Pre-Treatment. Acta Biologica Szegediensis, 46, 55-57.

[9] Edward, A.K. and Bison, M.A. (1996) Plasma Membrane $\mathrm{Na}^{+}$Transport in Salt Tolerant Halophytes. Plant Physiology, 111, 1191-1197.

[10] Patade, V.Y., Bhargava, S. and Suprasanna, P. (2009) Halopriming Imparts Tolerance to Salt and PEG Induced Drought Stress in Sugarcane. Agriculture, Ecosystems and Environment, 134, 24-28.

[11] Jafar, M.Z., Farooq, M., Cheema, M.A., Afzal, I., Basra, S.M.A., Wahid, M.A., Aziz, T. and Shahid, M. (2012) Improving the Performance of Wheat by Seed Priming under Saline Conditions. Journal of Agronomy and Crop Science, 198, 38-45.

[12] Demir, I. and Van De Venter, H.A. (1999) The Effect of Priming Treatments on the Performance of Watermelon Seeds under Temperature and Osmotic Stress. Seed Science and Technology, 27, 871-875.

[13] Kaya, M.D., Okcu, G., Atak, M., Cıkılı, Y. and Kolsarıcı, O. (2006) Seed Treatments to Overcome Salt and Drought Stress during Germination in Sunflower (Helianthus annus L.). European Journal of Agronomy, 24, 291-295.

[14] Afkari, A. (2010) The Effects of $\mathrm{NaCl}$ Priming on Salt Tolerance in Sunflower Ger- 
mination and Seedling Grown under Salinity Conditions. African Journal of Biotechnology, 9, 1764-1770. https://doi.org/10.5897/AJB10.1019

[15] Sarmadnia, Gh.H. (1995) Principles of Seed Science and Technology. Jihad-University Press, $288 \mathrm{p}$.

[16] Khaleghi, A. and Moallemi, N. (2009) The Effect of Different Levels of Salinity and Temperature on Seed Germination of Cocks Comb. Journal of Plant Production Research, 16, 149-163.

[17] Agrawal, R. (2003) Seed Technology. Oxford Press, New Delhi, India, 829 p.

[18] Khoshkhoi, M. (2005) Plant Propagation: Principle and Practices. Shiraz University Press, Shiraz, $983 \mathrm{p}$.

[19] Singh, K.N., Sharma, D.K. and Chillar, R.K. (1988) Growth, Yield and Chemical Composition of Different Oil Seed Crop as Influenced by Sodicity. The Journal of Agricultural Science, 3, 459-463. https://doi.org/10.1017/S0021859600083635

[20] Hardegree, S.P. and Emmerich, W.E. (1990) Partitioning Water Potential and Specific Salt Effect on Seed Germination of Four Grasses. Annuals of Botany, 65, 587595. https://doi.org/10.1093/oxfordjournals.aob.a088068

[21] Aameur, F. and Sipple-Michmer-Huizen, J. (2001) Germination and Seedling Survival of Argan (Argania spinosa) under Experimental Saline Condition. Journal of Arid Environments, 49, 533-540. https://doi.org/10.1006/jare.2001.0804

[22] Ghoulam, C. and Fares, K. (2001) Effect of Salinity on Seed Germination and Early Seedling Growth of Sugar Beet (Beta vulgaris L.). Seed Science and Technology, 29, 357-367.

[23] Soleimani, F. and Ahmadvand, G. (2012) The Effect of Seed Priming on Germination of Cotton Seedling in Salinity Stress. Journal of Seed Science and Technology, 3, 31-43.

[24] Wang, H.Y., Chen, C.L. and Sung, J.M. (2003) Both Warm Water Soaking and Solid Priming Treatments Enhance Anti-Oxidation of Bitter Gourd Seeds Germinated at Sub-Optimal Temperature. Seed Science and Technology, 31, 47-56. https://doi.org/10.15258/sst.2003.31.1.06

[25] Hopper, N.W., Overholt, J.R. and Martin, J.R. (1979) Effect of Cultivar, Temperature and Seed Size on the Germination and Emergence of Soy Beans (Glycine max (L.) Merr.). Annuls of Botany, 44, 301-308. https://doi.org/10.1093/oxfordjournals.aob.a085733

[26] Ghana, S.G. and Schillinger, W.F. (2003) Seed Priming Winter Wheat for Germination, Emergence and Yield. Crop Science, 43, 2135-2141. https://doi.org/10.2135/cropsci2003.2135

[27] Bose, B. and Mishra, T. (1992) Response of Wheat Seed to Pre-Sowing Seed Treatments with $\mathrm{Mg}\left(\mathrm{NO}_{3}\right)_{2}$. Annals of Agricultural Research, 13, 132-136.

[28] Taylor, A.G. and Harman, G.E. (1990) Concepts and Technologies of Selected Seed Treatments. Annual Review of Phytopathology, 28, 321-339. https://doi.org/10.1146/annurev.py.28.090190.001541

[29] Jamil, M., Lee, C.C., Rehman, S.U., Lee, D.B., Ashraf, M. and Rha, E.S. (2005) Salinity $(\mathrm{NaCl})$ Tolerance of Brassica Species at Germination and Early Seedling Growth. Electronic Journal of Environmental, Agricultural and Food Chemistry, 4, 970-976.

[30] Farooqh, M., Basra, S.M.A. and Rehman, H. (2006) Seed Priming Enhances Emergence, Yield, and Quality of Direct-Seeded Rice. International Rice Research Notes, 31, 42-46.

[31] Murungu, F.S., Nyamugafata, P., Chiduza, C., Clark, L.J. and Whalley, W.R. (2003) Effects of Seed Priming, Aggregate Size and Matric Potential on Emergence of Cot- 
ton (Gossypium hirsutum L.) and Maize (Zea mays L.). Soil and Tillage Research, 74, 161-168.

[32] Yagmur, M. and Kaydan, D. (2008) Alleviation of Osmotic Stress of Water and Salt in Germination Lotus corniculatus L. Seed Science and Technology, 31, 455-463.

[33] Kattimani, K.N., Reddy, Y.N. and Rao, B.R. (1999) Effect of Pre-Sowing Seed Treatment on Germination, Seedling Emergence, Seedling Vigor, and Root Yield of Ashwagandha (Withania somnifera Daunal.). Seed Science and Technology, 27, 483-488.

[34] Artola, A., Carrillo-Castaneda, G. and Santos, G.D.L. (2003) Hydropriming: A Strategy to Increase and Seedling Growth of Triticale with Seed Priming Treatments. African Journal of Crop Science, 43, 2135-2141.

Submit or recommend next manuscript to SCIRP and we will provide best service for you:

Accepting pre-submission inquiries through Email, Facebook, LinkedIn, Twitter, etc. A wide selection of journals (inclusive of 9 subjects, more than 200 journals) Providing 24-hour high-quality service User-friendly online submission system Fair and swift peer-review system Efficient typesetting and proofreading procedure Display of the result of downloads and visits, as well as the number of cited articles Maximum dissemination of your research work

Submit your manuscript at: http://papersubmission.scirp.org/

Or contact oje@scirp.org 